\title{
Mapping human pressures across the planet uncovers anthropogenic threat
}

\section{complexes}

D.E. Bowler ${ }^{1-4^{*}}$, A.D. Bjorkman ${ }^{5}$, M. Dornelas $^{6}$, I.H. Myers-Smith ${ }^{7}$, L. M. Navarro ${ }^{2,8}$, A. Niamir $^{1}$, S.R. Supp ${ }^{9}$, C. Waldock ${ }^{10}$, M. Vellend ${ }^{11}$, S. A. Blowes ${ }^{2,12}$, K. Böhning-Gaese ${ }^{1}$, H.

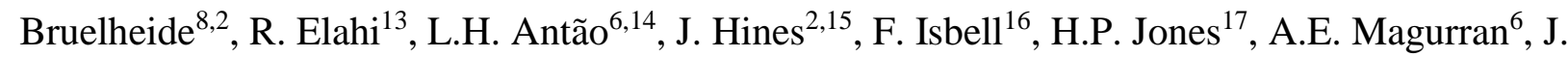
S. Cabral ${ }^{2,18}$, M. Winter ${ }^{2,19}$, \& A.E. Bates ${ }^{10,20}$

${ }^{1}$ Senckenberg Biodiversity and Climate Research Centre, Senckenberganlage 25, D-60325

Frankfurt am Main, Germany.

${ }^{2}$ German Centre for Integrative Biodiversity Research (iDiv) Halle-Jena-Leipzig, Deutscher Platz 5e, 04103 Leipzig, Germany

${ }^{3}$ Institute of Biodiversity, Friedrich Schiller University Jena, Dornburger Straße 159, 07743 Jena, Germany

${ }^{4}$ UFZ - Helmholtz Centre for Environmental Research, Department of Ecosystem Services, Permoserstr. 15, 04318 Leipzig, Germany

${ }^{5}$ Section for Ecoinformatics \& Biodiversity, Department of Bioscience, Aarhus University, DK8000 Aarhus, Denmark.

${ }^{6}$ Centre for Biological Diversity, University of St Andrews, Sir Harold Mitchell Building, St Andrews, KY16 9TH Scotland, UK.

${ }^{7}$ School of GeoSciences, University of Edinburgh, Edinburgh EH9 3FF, UK

${ }^{8}$ Institute of Biology/Geobotany and Botanical Garden, Martin Luther University HalleWittenberg, Am Kirchtor 1, 06108 Halle, Germany. 
${ }^{9}$ Denison University, Data Analytics Program, Granville, OH 43023 USA

${ }^{10}$ Ocean and Earth Science, National Oceanography Centre Southampton, University of Southampton, Waterfront Campus, European Way, Southampton, SO14 3ZH, United Kingdom

${ }^{11}$ Université de Sherbrooke, Sherbrooke, QC Canada J1K 2R1

${ }^{12}$ Department of Zoology, George S. Wise Faculty of Life Sciences, Tel Aviv University, Tel Aviv 69978, Israel

${ }^{13}$ Hopkins Marine Station, Stanford University, Pacific Grove, CA 93950, USA

${ }^{14}$ Department of Biology and CESAM, Universidade de Aveiro, Campus Universitário de Santiago, 3810-193, Aveiro, Portugal

${ }^{15}$ Institute of Biology, Leipzig University, Deutscher Platz 5e, 04103 Leipzig, Germany

${ }^{16}$ Department of Ecology, Evolution, and Behavior, University of Minnesota Twin Cities, Saint Paul, Minnesota 55108, USA

${ }^{17}$ Department of Biological Sciences and Institute for the Study of the Environment, Sustainability, and Energy. Northern Illinois University, DeKalb, IL 60115, USA.

${ }^{18}$ Ecosystem Modeling, Centre for Computational and Theoretical Biology, University of Würzburg, Würzburg, Germany

${ }^{19}$ Leipzig University, Ritterstraße, 26, 04109 Leipzig, Germany

${ }^{20}$ Department of Ocean Sciences, Memorial University of Newfoundland, St. John's A1C 5S7, Canada

*Correspondence to: diana.e.bowler@gmail.com 


\section{Abstract}

1. Climate change and other anthropogenic drivers of biodiversity change are unequally distributed across the world. Overlap in the distributions of different drivers have important implications for biodiversity change attribution and the potential for interactive effects. However, the spatial relationships among different drivers, and whether they differ between the terrestrial and marine realm has yet to be examined.

2. We compiled global gridded datasets on climate change, land-use, resource exploitation, pollution, alien species potential, and human population density. We used multivariate statistics to examine the spatial relationships amongst the drivers and to characterize the typical combinations of drivers experienced by different regions of the world.

3. We found stronger positive correlations among drivers in the terrestrial than in the marine realm, leading to areas with high intensities of multiple drivers on land. Climate change tended to be negatively correlated with other drivers in the terrestrial realm (e.g., in the tundra and boreal forest with high climate change but low human use and pollution), whereas the opposite was true in the marine realm (e.g., in the Indo-Pacific with high climate change and high fishing).

4. We show that different regions of the world can be defined by anthropogenic threat complexes (ATCs), distinguished by different sets of drivers with varying intensities. The ATCs can be used to test hypotheses about patterns of biodiversity change, especially in response to the joint effects of multiple drivers. More generally, our global analysis highlights the broad conservation priorities needed to mitigate the impacts of 
bioRxiv preprint doi: https://doi.org/10.1101/432880; this version posted July 9,2019 . The copyright holder for this preprint (which was not certified by peer review) is the author/funder, who has granted bioRxiv a license to display the preprint in perpetuity. It is made available under aCC-BY-NC-ND 4.0 International license. 


\section{Introduction}

Human activities are reshaping biological communities and impacting ecosystem functioning across the Earth (Barnosky et al. 2011; Dornelas et al. 2014; Isbell et al. 2017). Meeting the global challenge of the conservation and sustainable use of nature requires not only quantifying biodiversity change, but also identifying the underlying causes of change (Tittensor et al. 2014; Isbell et al. 2017). Climate change, habitat change, exploitation, pollution and invasive alien species have been recognized as the most important and widespread direct causes of biodiversity change (Pereira, Navarro \& Martins 2012; IPCC 2013; IPBES 2019). These five main drivers have been linked with changes in multiple dimensions of biodiversity, including genetic diversity, species' population sizes and the functional diversity of communities (Pereira, Navarro \& Martins 2012). The impacts of these drivers on a biological community in a given region critically hinge on the extent of exposure to each driver, which refers to its local magnitude or change (such as the strength of climate change or intensity of land-use). An important, but so far underexplored, step towards understanding the global patterns of biodiversity change is characterizing the exposure patterns of biological communities to different types of environmental change.

Global maps of pressures such as the terrestrial human footprint (Sanderson et al. 2002; Venter et al. 2016), marine pressures (Halpern et al. 2008; Halpern et al. 2015a) and river threats (Vorosmarty et al. 2010) characterize the geographic hotspots of anthropogenic threats to biodiversity. These maps have estimated that at least $75 \%$ of terrestrial land has been exposed to some sort of land-use change (Venter et al. 2016), while the marine realm has been exposed to multiple pressures (Halpern et al. 2015a). The intensity of the terrestrial human footprint has been linked with spatial variation in ecological processes; for instance, reduced animal 
movement was found in areas with a higher human footprint across different species (Tucker $e t$ al. 2018). However, these global maps show the summed pressure of different drivers related to human activities and ignore any relationships among them. Areas identified as having high human pressure could be underlaid by different combinations of drivers with varying intensity, each of which may have contrasting impacts on biodiversity. Hence, while useful, these cumulative threat maps do not help understand the relative contribution of each driver to global biodiversity change, nor the potential for interactive impacts among drivers.

The relative importance of different drivers for biodiversity change and ecosystem services is a key component of both policy-oriented assessments such as IPBES framework (Diaz et al. 2015) and conservation targets such as CBD Aichi Biodiversity Targets (Tittensor et al. 2014). Hence, unpacking the spatial patterns of exposure of different drivers, and assessing the extent to which they jointly act on communities, is an important line of research. Many studies have examined the relationships between different anthropogenic drivers and biodiversity change, such as change in biological communities (richness, composition and population abundances), but they usually focus on only one or two drivers, such as climate change and land use change (Sirami et al. 2017). Multiple drivers may be associated with each other, either coincidentally (due to shared causes) or causally (when one driver affects the intensity of another) (Geary et al. 2019). Moreover, when drivers co-occur, their impacts on communities may be additive, or interact synergistically (total impact stronger when together) or antagonistically (total impact weaker when together) (Cote, Darling \& Brown 2016; Sirami et al. 2017). Nonetheless, few studies have examined the effects of multiple drivers on biodiversity (Sirami et al. 2017; Mazor et al. 2018). 
Here, we analyzed the spatial relationships among variables related to the main drivers of

113 biodiversity change, and show how they overlap in different biogeographic regions across the

114 entire surface of the world. The motivation for our study was primarily to advance the study of

115 the attribution of biodiversity change, especially regarding potential drivers of long-term changes

116 in species' populations and communities (Dornelas et al. 2014; Bowler et al. 2017; Dornelas et

117 al. 2019). Hence, our questions were focused towards the relevance of the spatial patterns of

118 drivers for biodiversity change rather than on explaining the spatial patterns in drivers

119 themselves. We determined the extent of driver overlap to assess the potential for different

120 drivers to either act alone on communities, rendering their specific fingerprints easier to detect,

121 or for drivers to act in combination, with the potential for interactive effects. For many drivers, it

122 can be hypothesized that exposure patterns may be inter-linked due to related local or regional

123 human activities, driven by local human population density (Ellis et al. 2010; Geary et al. 2019).

124 In contrast, climate change is expected to be distributed differently to other variables because it

125 is an outcome of processes at regional and global scales (IPCC 2013).

Towards these aims, we compiled global spatial gridded datasets on variables that

127 characterize different anthropogenic drivers (Tables 1 and S1-S2). Although the specific

variables differ among realms, we aligned each variable to the dominant drivers that are common

129 across both realms (Table 1). We quantified the strengths of the spatial relationships among the

130 intensities of the different variables related to climate change, habitat conversion and

131 exploitation (grouped together as 'human use'), pollution and potential for alien species

132 immigration. Based on these relationships, we defined 'anthropogenic threat complexes' that

133 typify the combinations of drivers impacting different regions of the world. Studies mapping

134 drivers of biodiversity change have so far considered the terrestrial and marine realms separately. 
By employing a standardized analysis for both realms, our study also highlights similarities and differences in anthropogenic environmental changes across the world, including across realms.

\section{Methods}

\section{Approach to data selection}

By drivers, we refer to anthropogenic drivers only and not biological processes, such as dispersal and demographic rates, that more proximately lead to changes in species' abundances. Our analysis required datasets that were (1) global; (2) spatially gridded at high-resolution and (3) publicly available. We selected datasets on variables related to the main five drivers that were included in previous studies of global environmental change in the context of biodiversity change (Table 1) (Sanderson et al. 2002; Halpern et al. 2008). We further searched for data on other relevant variables following the IUCN threats categories (Table S1) (Salafsky et al. 2008). As we focused on a land versus ocean comparison, we did not specifically consider freshwater threats (Vorosmarty et al. 2010). Variables representing drivers of biodiversity change were in most cases based on data between 1990 and 2010 (except climate change, and forest loss; see below). In total, we had datasets for 16 driver-related variables (Table 1). The terrestrial datasets came from various sources (Table S2). Most of the marine datasets came from the landmark study of Halpern et al. (Halpern et al. 2008). For interpretation and presentation purposes, variables were grouped into five broad categories: climate change, habitat conversion, exploitation, pollution and alien species potential. Because habitat conversion and exploitation were difficult to classify separately across terrestrial and marine ecosystems, we combined both into a single "human use" category. 
Climate change has multiple components (IPCC 2013), hence we characterized climate change by several variables using global spatiotemporal gridded temperature data for the terrestrial

161 (Harris et al. 2014) and marine realm (Rayner et al. 2003). To calculate temperature trends, we

162 used data between 1950, proposed as the start of the Anthropocene (Waters et al. 2016), and 2010. Temperature trends were estimated by fitting simple linear regression models to annual

164 temperature means of each grid cell and extracting the coefficient for the effect of year.

165 Temperature divergence was inferred from the t-statistic of this linear regression, i.e., the trend

166 divided by its standard error, representing the significance of the trend. Velocity of climate

167 change (Loarie et al. 2009) was calculated as the ratio between the temporal temperature trend

168 and the local spatial gradient in temperature. Trends of extreme temperatures were calculated by

169 whichever was largest of the temporal trends in mean temperature of the warmest or coolest

170 month. We further included aridity for the terrestrial realm and ocean acidification for the marine

171 realm. The aridity trend was estimated by taking monthly and annual datasets on potential

172 evapotranspiration and precipitation, and calculating the monthly:annual ratio (Zorner et al.

173 2008), followed by the temporal trend of the annual monthly average of this ratio. Ocean

174 acidification, from the Halpern layers, was based on the change in aragonite saturation state

175 between 1870 and 2000-2009 (Halpern et al. 2008). 
In the terrestrial realm, we collated human use variables related to different types of land conversion or use: cropland, pasture land, cattle density, urban area and forest loss. Data on crop land, pasture land and urban/built land-cover were taken from different databases, primarily based on satellite imagery - crop land (Fritz et al. 2015), pasture land (Ramankutty et al. 2008) and urban land (Friedl et al. 2010). We additionally included information on forest loss since deforestation itself is a recognized threat (Barlow et al. 2016). Forest loss, based on FAO (Food and Agriculture Association of the United Nations) wood harvest statistics, was calculated as the loss of primary forest for the same time frame as our climate change statistics, i.e., between 1950 and 2010 (Hurtt et al. 2011). We also included data on cattle density, which was based on subnational livestock data that were statistically downscaled using multiple predictors (Robinson $e t$ al. 2014). In the marine realm, human use variables were based on different commercial fishing activities separated by gear types (e.g., dredging or cast nets), which determine their selectivity and impact on the surrounding seascape (Halpern et al. 2008). These fishing types were pelagic low-bycatch, pelagic high-bycatch, demersal habitat-modifying, demersal non-habitat-modifying low-bycatch, and demersal non-habitat-modifying high bycatch. These data were based on FAO and other commercial catch data sources and downscaled based on an ocean productivity model (Halpern et al. 2008).

\section{Pollution}

Nitrogen from both fossil fuel combustion and agriculture is one is the biggest pollutants impacting biodiversity (De Schrijver et al. 2011). We included data on nitrogen pollution for the terrestrial realm in the form of atmospheric nitrogen (Dentener 2006) and fertilizer use (Potter $e t$ al. 2010), and for the marine realm as fertilizer use (Halpern et al. 2008). We also included data 
on pesticide use in both realms (Halpern et al. 2008; Vorosmarty et al. 2010), another important component of agricultural intensification that negatively affects biodiversity (Geiger et al. 2010). Country-specific estimates of fertilizer use and pesticide were downscaled to a raster grid by the data providers according to crop land-cover maps; thus, these datasets were not fully independent of the cropland data, but they still represent the best current knowledge of the spatial distribution of these variables. We also included a layer estimating the extent of ocean pollution, based on the distribution of shipping lanes (Halpern et al. 2008). Finally, we included night-time light pollution detected by satellite imagery (Halpern et al. 2015a), which was also included in previous terrestrial and marine threat maps (Halpern et al. 2015a; Venter et al. 2016).

\section{Alien species potential}

The spread of alien species is among the greatest threats to biodiversity and ecosystem services (Blackburn, Bellard \& Ricciardi 2019). Alien species are defined as species that are introduced into areas beyond their historical range, usually through human transport, accidentally or incidentally (Hulme 2009; Seebens et al. 2015). We used information on transport infrastructure related to human movement and trade that depict possible species transportation pathways and vectors (Hulme 2009; Davidson et al. 2018). Specifically, we used spatial datasets of transport connectivity (including data on road and rail networks and navigable rivers) in the terrestrial realm and cargo volume at ports in the marine realm (Table S1). While these do not represent the only invasion pathways, they are commonly accepted proxies for human-mediated propagule pressure, which is known to be among the most important determinant of alien species establishment (Hulme 2009; Seebens et al. 2015). 
We note two limitations of our alien species data. First, our proxy was for alien species in general and not specifically for invasive and harmful alien species. Only a proportion of alien species become invasive, but this proportion differs among taxa (Jeschke \& Pyšek 2018). Although the most harmful alien species have been identified for some regions (Katsanevakis $e t$ al. 2014), this is an on-going process at the global level (Pagad et al. 2018). Hence, we refer to this variable as alien species potential rather than specifically as invasive alien species. Second, we only used a proxy for alien species propagule pressure and not direct measures of their distribution. Our analysis required high-resolution global gridded maps, but these are not available for alien species distributions for neither realm. However, information on alien species distribution was available at a regional, sub-national and national levels for some taxonomic groups, including birds (Dyer et al. 2017) and plants (van Kleunen et al. 2019). To assess the validity of our connectivity proxy, we used these datasets, representing taxa with low and high mobility, to test the correlation between alien species richness and mean connectivity at the spatial scale of the distribution data. We found a significant rank correlation for both datasets

237 (birds, $\rho=0.42$; plants, $\rho=0.46$, see Fig. S1 for more details), suggesting our proxy represents a reasonable approximation of alien species potential.

\section{Human population}

241 We also included "human population density" as a separate driver (CIESIN 2017) accounting for

242 the effects of human activities not falling into the other categories (Salafsky et al. 2008).

243 Including human population density also allowed quantitative tests of the relationship between

244 human population density and the other drivers. 


\section{Justification for layer exclusion}

We did not use data for some variables that were previously included in the terrestrial human footprint or the Halpern layers. The human footprint includes data on roads, railways and navigable waterways (Venter et al. 2016). Although we did not separately include these data, these data has been taken into account in the terrestrial connectivity variable (for invasions). In the marine realm, we excluded a shipping lane variable since the ocean pollution variable was already based on the distribution of shipping lanes (Halpern et al. 2008). Additional available marine layers that we did not use were: UV radiation, oils rigs (based on night lights, already included), inorganic pollution (highly correlated with other land-based coastal pollutants that were already included) and artisanal fishing (data poor and mostly modelled) (Halpern et al. 2008).

\section{Geographic region data}

To understand how the driver distributions compared with classic biome distributions that are already used in biodiversity research, we also extracted geographic region data on biomes. Data on the spatial distribution of terrestrial biomes (including deserts, temperate broadleaf forest and boreal forest among other) were taken from WWF (Olson et al. 2001). Marine regions were defined by combining coastal/shelf region polygon data - MEOW (Spalding et al. 2007) and ocean polygon data (naturalearthdata.com). We did not use marine ecosystem data as used by others (Halpern et al. 2015a) because the ecosystems spatially overlapped in our 2-D global raster grid, when, in reality, these different ecosystems occur at different depths in the water column. 
Data processing

We harmonized each dataset to a standard global grid. The resolutions of the original datasets were approximately at a $100 \mathrm{~km}$ square grid (or $1^{\circ}$ ) or finer resolution; hence, we aggregated all datasets to a standard grid of $100 \mathrm{~km}$ square grid cells by taking the mean value of the grid cells. Atmospheric nitrogen deposition was only available at a coarser resolution (see Table S1); however, we disaggregated this also to $100 \mathrm{~km}$. Datasets were bound between latitudes of -58 and 78 (due to poorer data at extreme latitudes) and re-projected onto a common equal-area map projection (Eckert IV; ESPG = 54012). Missing values in some of the human activity datasets (primarily in pesticide use) occurred in remote regions (e.g., very high latitudes and deserts) with likely absent or low variable values (since they were in areas with no crop cover) and were imputed as zero. Greenland was excluded due to missing data in several of the datasets.

Because each dataset comprised data in different units (e.g., temperature data in ${ }^{\circ} \mathrm{C}$ and fertilizer data in $\mathrm{kg} / \mathrm{ha}$ ), it was not possible to directly compare their absolute values. Instead, we ranked scaled (between 0 and 1) values of each dataset for ease of interpretation (Fig. S2 shows

283 the distributions of the original values of each variable and Fig. S3 shows global maps of the ranked and scaled data). This processing also reduced the large skew in the absolute values of many datasets. For most datasets, larger values reflected a greater magnitude, and thus higher potential exposure of biodiversity to that variable. Transformations were needed in only one case

287 - we inverted terrestrial accessibility (i.e., values ${ }^{-1}$ ). For climate change metrics, we only used 288 positive values to focus on the drivers of warming and drying. By using ranks, we avoided making any complex assumptions about the relationships between the absolute values of each 
driver variable and its impact on organisms. We rather assumed that all variables were similarly important and that higher variable values would have a stronger impact on biodiversity.

\section{Data analysis}

To examine the relationships among the intensities of the 16 different variables, we calculated Spearman's rank correlation coefficients $(\rho)$ for each pairwise combination of variables across all grid cells in each realm. We chose this statistic because it is equivalent to the commonly used Pearson's correlation on ranked data, which was consistent with our aforementioned data processing. We used Dutilleul's modified t-test to account for spatial autocorrelation before testing the significance of the correlations (Dutilleul, Pelletier \& Alpargu 2008). We also used Moran's I and correlograms to assess the extent of spatial autocorrelation within each variable. For the marine realm, correlations were also examined separately for grid cells whose centroid overlapped with oceanic or coastal regions. To assess the importance of the drivers in different parts of the world, we compared the average intensity of each of the five main drivers (climate change, human use, human population, pollution and alien species potential) for different geographic regions. We first calculated the mean driver value for each grid cell, i.e., averaging across associated driver-related variables (Table 1). We then plotted the distribution of these mean values across all grid cells within each terrestrial biome and marine region.

We used k-medoid clustering, with the partitioning around the medoids algorithm with Euclidean distances (Maechler et al. 2018), for clustering grid cells according to their extent of exposure of all the variables. To focus the clustering on the main axes of variation, we first used PCA to reduce the number of variables in driver groups with multiple variables, i.e., climate change, human use and pollution. We performed the clustering with two or three PCA 
components (whichever captured at least $75 \%$ of the variation) for each of these drivers along with the variables for human population density and potential alien species. We selected the number of clusters by comparing the changes in cluster silhouette width with increasing cluster number; however, we limited the cluster number to $<10$. To slightly smooth the maps, we used a moving window to assign each cell the mode of its $3 \times 3$ cell neighborhood. Although, driver combinations vary in a continuous manner, we chose a clustering method that produces discrete grouping to provide the simplest description of the main groupings in the data. Finally, to repack the datasets into cumulative driver maps, we summed the number of variables for which each grid cell was in the upper $10 \%$ of values (based on values greater than zero). Analyses were run in R v. 3.4.1 (R Core Team 2018), using the packages raster (Hijmans 2017), SpatialPack (Vallejos, Osorio \& Bevilacqua 2018) and cluster (Maechler et al. 2018).

\section{Sensitivity analyses}

To examine the effect of the grain size, we repeated the data processing steps except harmonized the datasets to a global grid of $500 \mathrm{~km}$ resolution and repeated the correlation analysis (similar results were obtained - see Fig. S4). To check the effects of ranking the data values, we repeated the data processing steps by logging the values (to the base 10) rather than ranking them, after bounding extreme values to the upper and lower $2.5 \%$ quantiles. This alternative data transformation does not affect the correlation coefficients because Spearman's correlations only uses the ranks of the data. We repeated our remaining analysis with this alternative transformation, calculating the average variable intensities for different terrestrial and marine regions, and the clustering analysis (generally similar results were obtained - see Fig. S5 and 
S6). Since the distributions are still skewed after logging instead of ranking, the patterns are strongly affected by extreme values with this approach, especially in the marine realm.

\section{Results}

We found that drivers of biodiversity change were more spatially coupled in the terrestrial than in the marine realm (Fig. 1, Fig. S7). On land, $40 \%$ of the possible pairwise relationships between variables (excluding climate change-related variables) showed positive correlation strengths of at least 0.7 . Thus, terrestrial areas with high intensities of one variable also tended to have high intensities of other variables. Moreover, correlations were found between different types of drivers; for instance, high crop land-cover was associated with high pollution, high alien potential and high human population density. Conversely, in the marine realm, we found fewer correlations - only $15 \%$ of the possible pairwise relationships (excluding climate change-related variables) showed a strong positive correlation (>0.7) - and these relationships were mostly within, rather than between, different driver types; for instance, among different types of human use (e.g., different types of demersal fishing; Fig. 1). Across all variables, oceanic regions showed fewer correlations compared to coastal regions (Fig. S8). Spatial autocorrelation was present in all variables and tended to reach greater distances in the marine human-uses and climate-change variables (Figs S9 and S10), and shorter distances in the coastal-based marine variables. However, the correlations among drivers were statistically significant (all $\mathrm{P}<0.05$ for links shown in Fig. 1) after accounting for autocorrelation. In neither realm were there strong negative correlations among variables (Fig. S11 shows the full correlation matrix). 
Strong correlations between climate change and non-climatic drivers (human use, pollution and alien species) were not observed in either realm (Fig. 1, Fig. S11); however, there were still significant weak correlations, with the direction of these correlations differing systematically between realms (Fig. 2). Temperature change, and its velocity, was negatively associated with the average intensity of other variables in the terrestrial realm (Fig. 2; temperature change: $\rho=-0.26, \mathrm{P}<0.01$; velocity: $\rho=-0.22, \mathrm{P}<0.01)$, but positively associated with the average intensity of other variables in the marine realm (Fig. 2 ; temperature change: $\rho=$ 0.20, $\mathrm{P}=0.06$; velocity: $\rho=0.24, \mathrm{P}<0.05)$. Pollution, cattle density and human population density were especially negatively correlated with temperature change in the terrestrial realm while human use (demersal and pelagic fishing) was especially positively correlated with temperature change in the marine realm (Fig. 2).

Consistent with the negative association between climate change and human use in the terrestrial realm, terrestrial biomes exposed to some of the strongest climate change, such as the tundra, boreal forest and desert, have experienced the lowest intensities of human use (Fig. 3, Fig. S12). By contrast, other terrestrial biomes, such as tropical dry broadleaf forest and tropical coniferous forest, have had high intensities of human use, pollution and invasions but lower intensities of climate change. Temperate broadleaf and mixed forest is distinct in the terrestrial realm by experiencing higher than average intensities of all drivers (Fig. 3). In the marine realm, central and western Indo-Pacific were most exposed to multiple drivers, including rapid climate change and multiple human uses, especially fishing (Fig. 3). The temperate Northern Atlantic, which includes the North Sea, has been also strongly exposed to multiple drivers. By contrast, the Pacific Ocean been exposed to the lowest intensities of multiple drivers. 
The cluster analysis defined five terrestrial and six marine regions according to their similarity of exposure to the different driver variables (Fig. 4). These exposure patterns can be regarded as 'anthropogenic threat complexes' (ATC) that characterize the typical combinations of environmental change emerging at large scales. ATCs I and VI (dark blue-grey regions in Fig. climatic drivers such as human use, pollution and alien potential. ATCs II and VII are regions (medium blue-grey) exposed to medium intensities of many variables, including climate change. ATCs IV and IX (red regions) were similarly exposed to medium intensities of many variables, but higher intensities of climate change. ATCs III and VIII (light blue) were exposed to relatively weaker climate change than to non-climatic drivers; by contrast, ATCs V and X (orange regions) were exposed to relatively greater climate change than to non-climatic drivers. ATC XI represents areas (light orange) that were exposed to low intensities of most variables and was only found in the marine realm. The largest terrestrial ATC was V (34\% of terrestrial grid cells), covering regions exposed to medium-high climate change and lower intensities of other drivers. The largest marine ATC was IX (23\% of marine grid cells), including regions exposed to both medium human use, especially fishing, and medium-high climate change. 2008; Halpern et al. 2015a). Terrestrial regions with the highest cumulative intensities across multiple drivers tended to be within ATC I, covering parts of Europe, Northeastern America, 
Atlantic, East China Sea and central Indo-Pacific. Terrestrial regions with the lowest cumulative intensities of multiple drivers were commonly within ATCs III and V, covering parts of South America, Africa, Russia and Australia. In the marine realm, the lowest cumulative intensities were within ATCs X and XI, in the Indian Ocean, the southern Atlantic Ocean and Pacific Ocean.

\section{Discussion}

Our findings suggest that many drivers of biodiversity change are unlikely to act alone, but rather to jointly impact biological communities. In the terrestrial realm, drivers that tend to be simultaneously present in a region were associated with agricultural activities (including land conversion to cropland, use of land for cattle rearing, use of pesticides/fertilizer), human population density (urban cover and light pollution) and potential for alien species. These drivers have especially high spatial overlap in the temperate broadleaf and mixed forests of eastern North America, Europe and China. In the marine realm, drivers that tend to spatially overlap include different types of pollutants and the potential for alien species, with the coastal regions of the Indo-Pacific and Northern Atlantic (especially the North Sea) showing the highest overlap. Taken together with recent studies that highlight the lack of research on interactive effects of drivers (Sirami et al. 2017; Mazor et al. 2018), our findings emphasize the widespread relevance of further research on understanding how multiple drivers combine to impact biological communities.

Correlations among drivers were more frequent in the terrestrial realm than in the marine realm. Spatial relationships among drivers in the terrestrial realm were likely based on different 
activities supporting proximal human populations, leading to simultaneous pressures from landuse change and pollution (Ellis et al. 2010). Indeed, Venter et al. (2016) already linked spatial variation in the human footprint to land suitable for agriculture. By contrast, in the marine realm, different types of human uses were based on different fishing activities that largely occur in different areas, leading to lower spatial overlap among them. For instance, demersal fisheries, such as bottom-trawling that disturbs the seabed, mostly occurs over the continental shelf; while, pelagic fisheries, such as longline fishing for species such as tuna, can be either continental or oceanic. Coastal regions were intermediate in patterns between terrestrial and oceanic regions, suggesting that local human populations contribute to the differences between the two realms (Halpern et al. 2015b). Different histories of human activities in the terrestrial and marine realm likely also plays a role. Human exploitation in the terrestrial realm is more advanced, spanning millennia, while technological advances have only recently allowed greater exploitation of the world's oceans (Knapp et al. 2017).

Climate change emerged from our analysis as a spatially distinct driver of biodiversity change. In both realms, climate change was only weakly associated with other drivers (human use, pollution and alien species), as expected based on the broad spatial scale at which carbon emissions affect climate. This finding suggests climate change impacts should be easier to isolate in statistical models from the impacts of other drivers, and that fingerprints of climate change impacts on species abundances, range limits and community compositions (Parmesan \& Yohe 2003; Poloczanska et al. 2013) may be easier to detect than those of other drivers. In the terrestrial realm, climate change tended to be greater in areas with lower human use. Indeed, high-latitude terrestrial regions that are experiencing pronounced climate change (IPCC 2013; Pithan \& Mauritsen 2014) have historically undergone less human settlement and agriculture. In 
areas where non-climatic drivers are weak, climate change has the potential to be the dominant driver of change, for instance in deserts, tundra and boreal forests of the terrestrial realm and in the south Atlantic Ocean and Indian Ocean of the marine realm.

Our classification of Anthropogenic Threat Complexes helps regard anthropogenic environmental change as a series of at least 11 large-scale natural experiments across the globe. The ATCs highlight where future research on the joint impact of multiple drivers, and their potentially interactive effects, could be most usefully directed to have the widest relevance for the study of biodiversity change. They suggest, for instance, that interactive effects between climate change and fishing should be further studied in the Indo-Pacific and North Sea, where both rapid temperature change and intense fishing have been occurring (Ramirez et al. 2017). In the terrestrial realm, biological communities in Europe may be of special interest to study the joint impacts of climate change, land use and pollution on different ecosystems because of the strong intensities of multiple drivers.

Attribution of observed biodiversity change to the underlying anthropogenic drivers may be most successful if focused on complexes of environmental change, rather than on each variable individually. Because of the correlations among drivers, relationships between a driver and a metric of biodiversity change may in fact be caused by a correlated driver. Although spatial heterogeneity at smaller spatial scales (e.g., neighboring sites that differ in only one driver, such as land-use change) can estimate the local effect of drivers such as habitat conversion (Newbold et al. 2015), correlated large-scale drivers can affect regional species pools and hence still influence local community dynamics (Harrison \& Cornell 2008). Analysis of the relationship between ATCs and species' declines may help identify the most harmful combinations of drivers. The ATCs could be resolved to finer spatial scales and also used to 
inform the design of biodiversity observatories that treat driver exposure as a natural experiment. Observatories could be selected along a given driver gradient, keeping all but this driver constant. Alternatively, study regions that are most suitable to study a specific driver could be selected from within geographic clusters dominated by the driver of interest, to reduce the confounding effects of other drivers in the landscape.

Large-scale information on drivers is most immediately relevant for global conservation policy (Tittensor et al. 2014; IPBES 2019). For biodiversity conservation at specific locations, local data on the magnitudes of different types of anthropogenic pressures are essential to decide on the most suitable management plan. However, even in this latter context, there are a number of advantages of having knowledge on the large-scale patterns of drivers. First, these large-scale patterns allow local management to be modified according to the wider anthropogenic land- or seascape context (Harrison \& Cornell 2008). Whilst landscape ecology and habitat connectivity already inform conservation planning, knowledge of all drivers present in the region could influence local decision-making by enabling prediction of possible future threats and biodiversity change at local-scales, e.g., large-scale land-use change affecting regional species pools, with consequences for local community changes through dispersal (Hansen \& DeFries 2007). Secondly, by characterizing regions of the world in terms of the nature of anthropogenic environmental change, the ATCs suggest how information and data might be pooled and synthesized across regions, and even across realms. Regions exposed to the same ATC, regardless of location, would benefit from exchanging knowledge about prioritization strategies and management of the multiple drivers, as well as implementing cross-border and inter-regional strategies to minimize their impact (Bonebrake et al. 2019). 

their past inclusion in global threat maps and their linkage to IUCN threat categories. However, many of the recognized IUCN threats to biodiversity (Salafsky et al. 2008; Joppa et al. 2016) were not available as high-resolution spatial datasets at a global scale, which was necessary for our analysis. These threats include energy production and mining, hunting, and other forms of human disturbance (Salafsky et al. 2008). Data availability was especially limited for the marine realm and the threat from invasive alien species globally. Rather than use proxy variables of species transport and thus of propagule pressure, spatially-explicit maps of the number of invasive alien species would have improved our analysis. The Global Register of Introduced and Invasive Species (www.griis.org) is working towards better knowledge of the distribution of 501 invasive species (Pagad et al. 2018). Our study only focused on spatial patterns and did not explicitly consider the consequences of changes in human activities over time. Ongoing projects such as the Copernicus project (http://www.copernicus.eu/) will greatly increase the availability of high-resolution spatiotemporal datasets on different variables in the coming years, enabling better attribution of biodiversity change to the underlying drivers. which species, in which places, are most impacted by human activities. However, the realized outcome of different drivers on biodiversity will ultimately depend on a combination of both the magnitude of exposure to drivers and species' sensitivities to environmental change (Foden et al. 2013). While exposure characterizes the amount of environmental change (e.g., temperature change in ${ }^{\circ} \mathrm{C}$ ), sensitivity refers to the tolerance of the biological community to that driver (e.g.,

512 abundance (or individual fitness) change per ${ }^{\circ} \mathrm{C}$ temperature change). We intentionally focused on exposure patterns so that our results were not species-specific and therefore potentially 
514 relevant for any taxa or ecosystem. Unlike exposure, sensitivities vary among taxa according to

515 characteristics such as their life history, traits and niche breadth (Sunday et al. 2015) and

516 therefore need to be examined separately for different taxa. Hence, despite similar exposure

517 patterns, we can expect a diversity of biodiversity responses within each ATC due to variation in 518 species' sensitivities.

Our macroecological approach to mapping the drivers of biodiversity change contributes to the development of broad conservation policy targeted toward the mitigation of specific driver complexes. Development of conservation strategies that simultaneously attempt to tackle multiple drivers are likely to be more efficient in the long-term (Bonebrake et al. 2019). The ATC framework emphasizes the fact that multiple drivers usually affect local and regional

524 biological communities and discourages the prevalent simplistic focus on one or two drivers. Much more research should focus on understanding the joint impacts of multiple drivers and how different drivers interact on biological communities. Our findings help direct some of these future studies by identifying which drivers most commonly overlap, and in which regions of the world. Finally, by taking a cross-realm approach, we hope to encourage information exchange

529 across regions of the world that are exposed to similar suites of drivers, regardless of environmental realm, and the development of joined-up conservation policies across national

531 borders and the terrestrial-marine interface.

\section{Data availability}

534 Table S2 shows the sources of each dataset and links to where each dataset can be downloaded.

535 Datasets produced during our analysis (raster layers shown in Figures 4 and 5) are available as 536 georeferenced TIFF files in the SOM. 
538 Code availability

539

540 R script to harmonize the raster to a standard grid is found here:

541 https://github.com/bowlerbear/harmonizeRasters

542 R script for the subsequent analysis is found here:

543 https://github.com/bowlerbear/geographyDrivers 


\section{Acknowledgments:}

This paper arose from discussions at the sChange Workshop (www.idiv.de/schange), which was supported by sDiv, the synthesis centre of iDiv, the German Centre for Integrative Biodiversity Research Halle-Jena-Leipzig. We thank all other participants of this workshop for the stimulating discussion and compilation of data that directly fed into this project. We thank the Associate Editor and two anonymous reviewers for comments on the manuscript. We also thank Suzanne Fritz, Mary O’Connor, Bob O’Hara and Gergana Dasklova for comments on a previous version of the manuscript. DB, JSC, JH, SAB \& MW were funded by the German Research Foundation (DB: Grant no BO 1221/23-1; JSC, JH, LMN, SAB \& MW: via iDiv: FZT 118). SRS was funded by the National Science Foundation, USA (NSF 1400911). LHA was supported by Fundação para a Ciência e Tecnologia, Portugal (POPH/FSE SFRH/BD/90469/2012). ADB was supported by The Danish Council for Independent Research - Natural Sciences (DFF 418100565). MD was funded by the Scottish Funding Council (MASTS, grant reference HR09011) and MD \& AEM by the ERC project BioTIME (250189) and BioCHANGE (727440). CW was supported by the Natural Environmental Research Council (grant number NE/L002531/).

\section{Author contributions}

DB performed the analyses and wrote the first outline of the paper with AEB. All authors designed the study and helped draft the manuscript. 


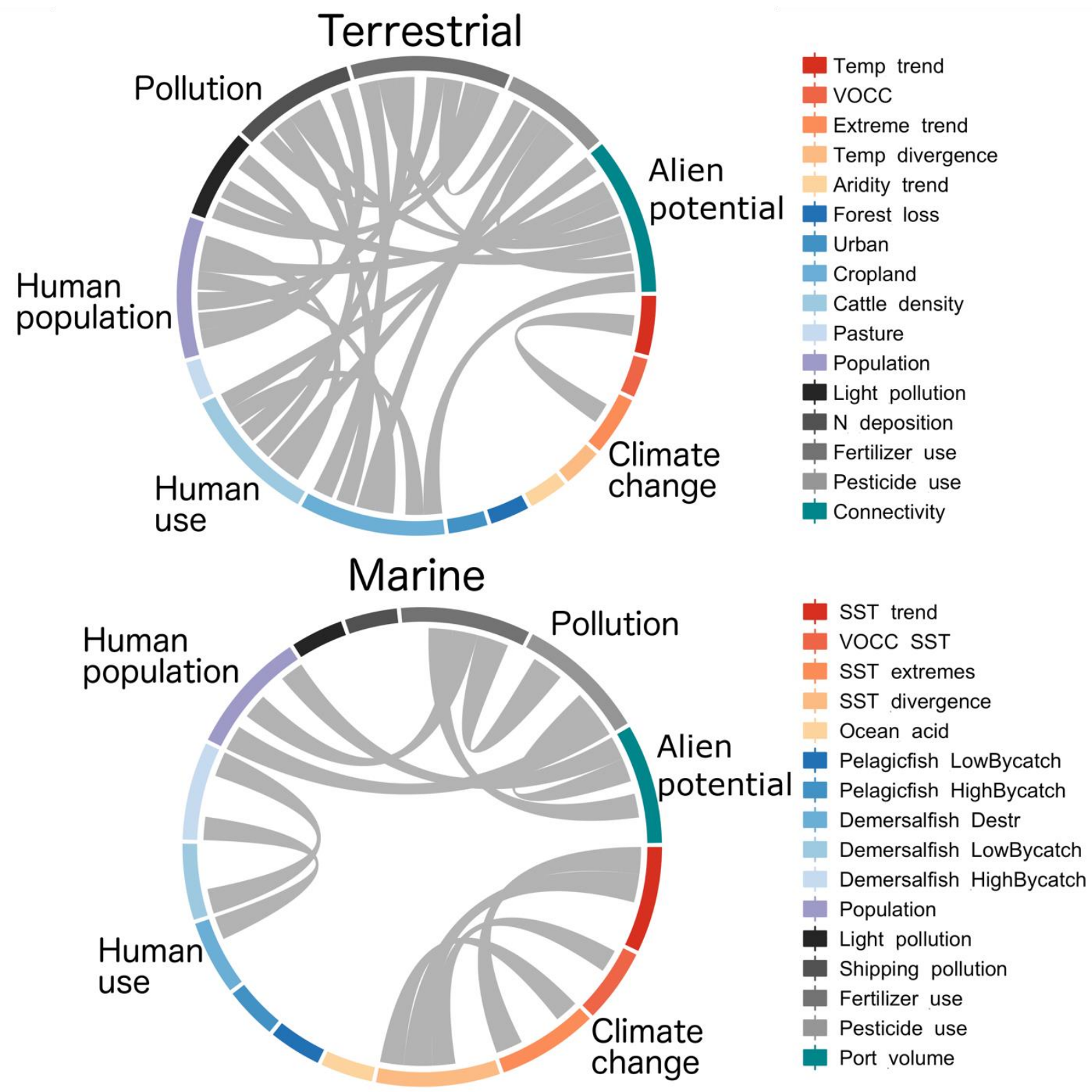

Fig. 1 Strong and positive relationships among anthropogenic drivers of biodiversity

change. Each grey link between two variables represents a significant positive correlation with strength $>0.7$ of the variable intensities across 100 square $\mathrm{km}$ grids covering each realm. We find a higher number of correlations between drivers in the terrestrial versus the marine realm. 


\section{Terrestrial}

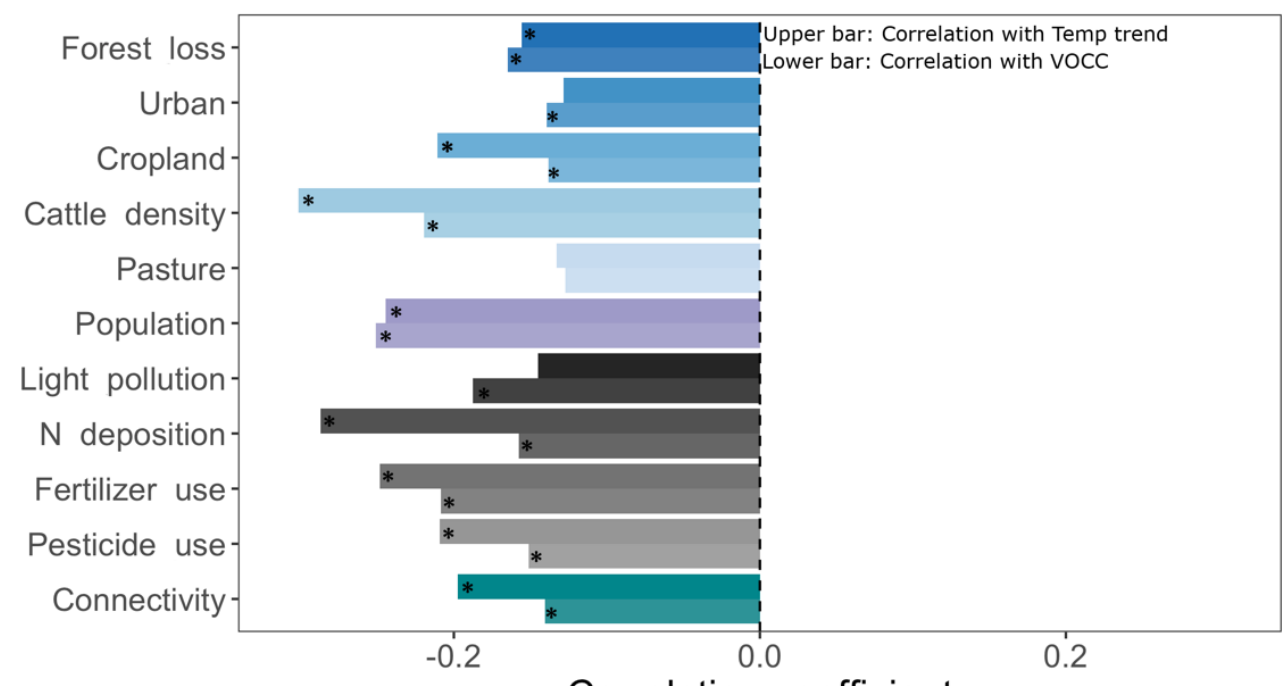

Marine

Correlation coefficient

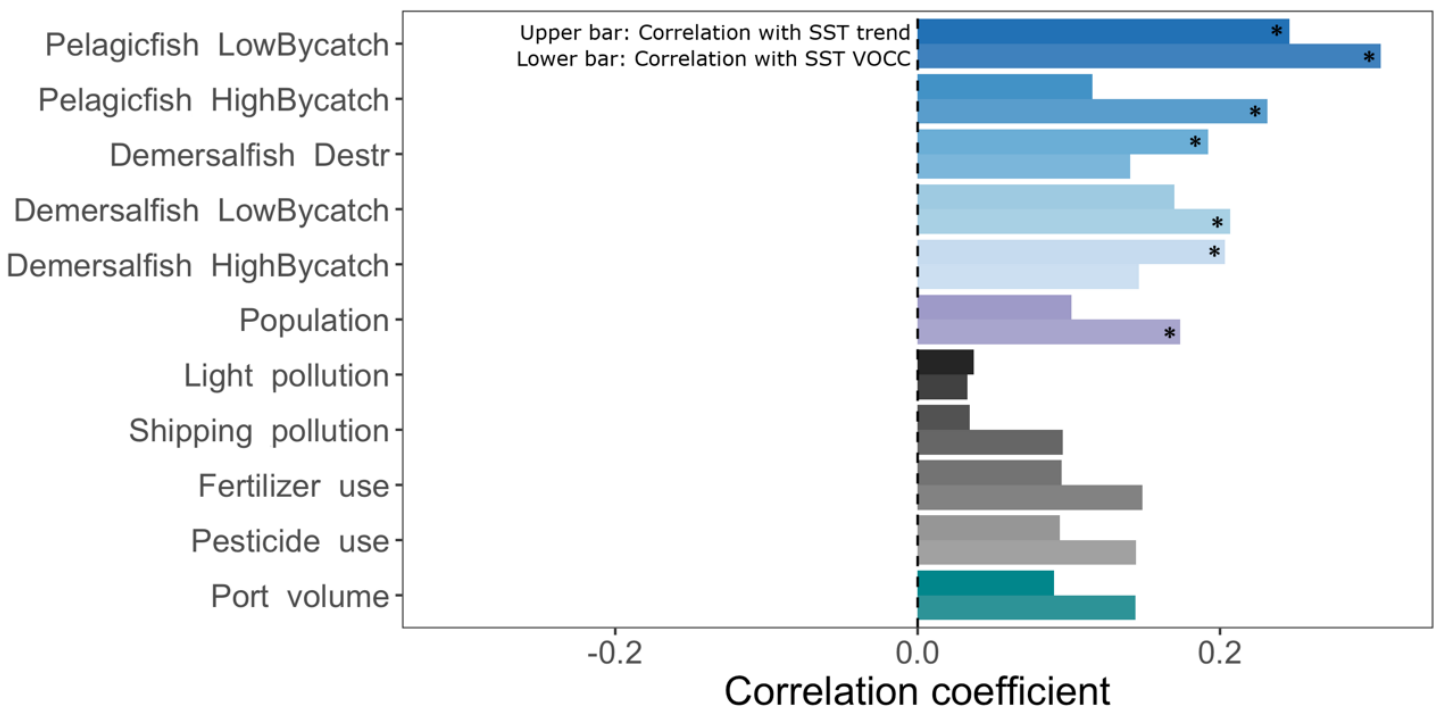

Fig. 2 Relationships between climate change and non-climatic drivers (human use,

pollution and alien species). The length of each bar represents the correlation coefficient

between each variable and temperature change (upper bar, air or sea surface temperature - SST)

or VOCC (lower bar, velocity of climate change). We find negative correlations in the terrestrial realm and positive correlations in the marine realm. * denotes statistical significance after accounting for spatial autocorrelation. 


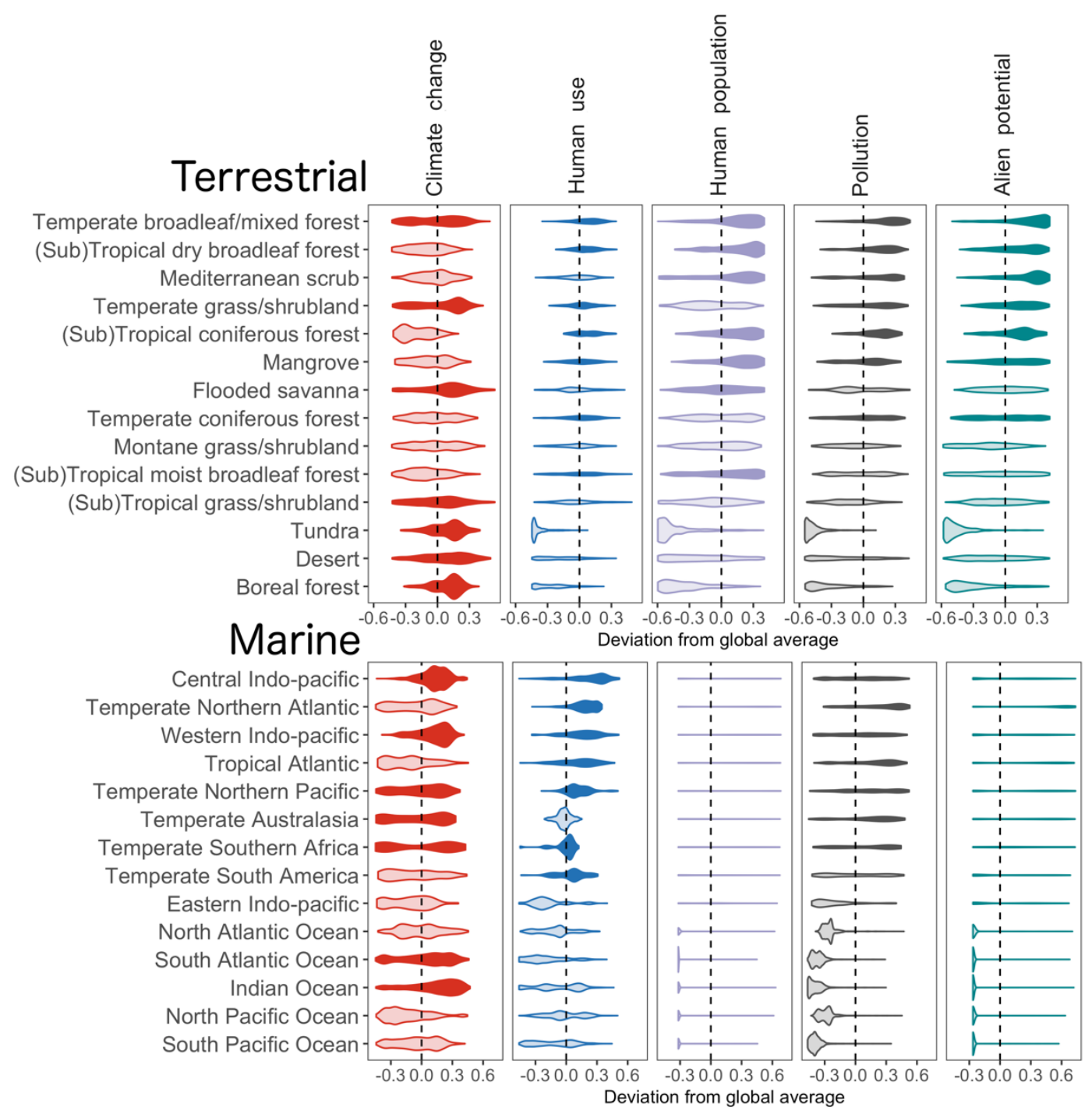

Fig. 3 Regions of the terrestrial and marine realms are exposed to distinct combinations of

drivers. The violin plots show the distribution of values for each driver in each region. Violins

with a median greater than the global median of each driver (the dashed zero line; median of

biome values) are colored in a darker shade. Regions are presented in declining order of total

driver exposure: regions at the top are exposed to the greater intensities of drivers and those at

the bottom are exposed to the least. Names of the terrestrial regions were shortened for

presentation purposes. Figure S12 shows the full distributions for each individual driver variable

in each region as well as gives the full names of the terrestrial regions. 


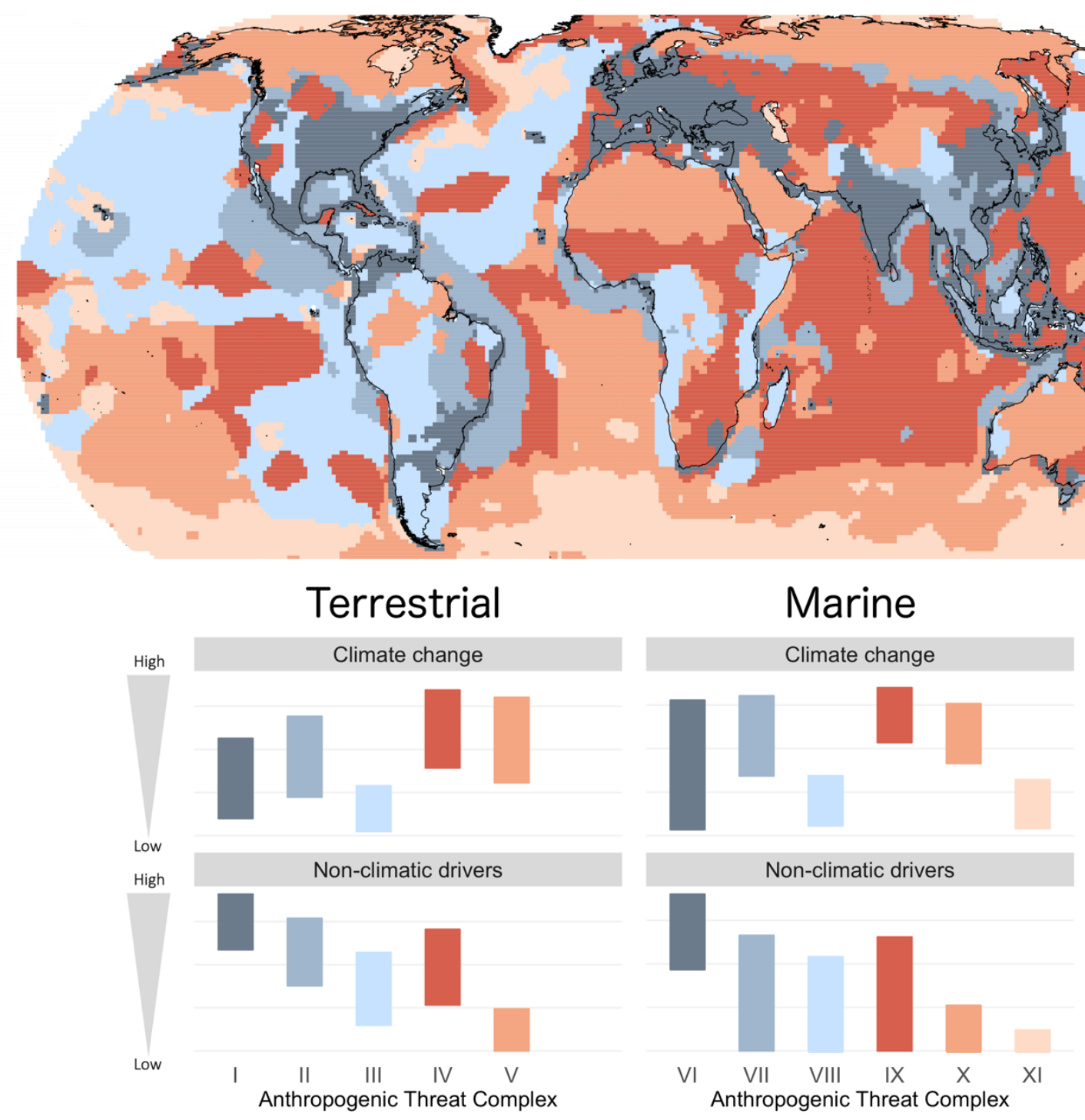

Fig. 4 Geography of the Anthropocene. Different geographic regions of the world are exposed to different Anthropogenic Threat Complexes (labelled I to XI). In the world map, each colour in each realm denotes a region exposed to the same ATC. The bar charts below are a legend for the colours of the map that describe the magnitudes of climate change and non-climatic drivers in each ATC. Similar ATCs across realms are shaded with the same colour. The bars represent the lower and upper quartiles of the intensities of variables within each driver group (climate change or non-climatic drivers that included human use, pollution and alien species potential). Fig. S13 provides the legend showing the full suite of variable intensities in each ATC. 

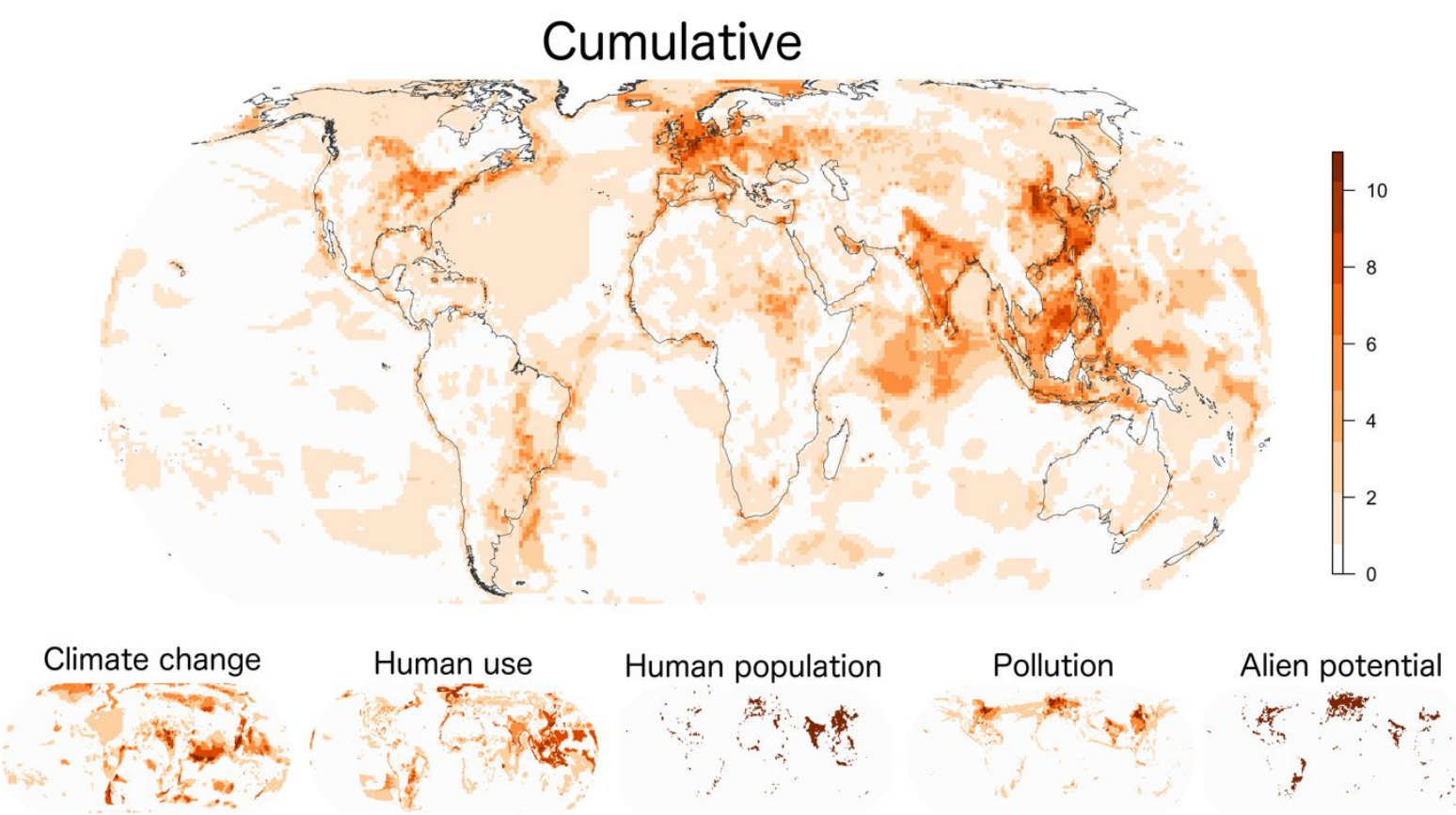

Fig. 5 Regions of the world exposed to high intensities of multiple drivers. The main map

shows the number of the 16 driver variables for which each grid cell was in the highest $10 \%$ of values within each realm. Regions in the darkest orange are exposed to high intensities of multiple variables, while those in off-white are exposed to lower intensities (i.e., within the $90 \%$ quantile of values) of all variables. The smaller plots below show the same for each of the separate drivers. Larger versions of the driver plots are presented in Fig. S14. 
Table 1 Anthropogenic drivers of biodiversity change and their respective variables based on available global spatial datasets (Tables S1 and S2). Variables in the same line do not necessarily represent the equivalent variable in each realm.

\begin{tabular}{|c|c|c|}
\hline \multirow{2}{*}{$\begin{array}{l}\text { Anthropogenic driver of } \\
\text { biodiversity change }\end{array}$} & \multicolumn{2}{|c|}{ Associated variables } \\
\hline & Terrestrial & Marine \\
\hline Climate Change & $\begin{array}{l}\text { Temperature trend } \\
\text { Temperature divergence } \\
\text { Change in climate extremes } \\
\text { Velocity of climate change } \\
\text { Aridity trend }\end{array}$ & $\begin{array}{c}\text { Temperature trend } \\
\text { Temperature divergence } \\
\text { Change in climate extremes } \\
\text { Velocity of climate change } \\
\text { Ocean acidification }\end{array}$ \\
\hline $\begin{array}{l}\text { Human use } \\
\text { (land/sea use or change, } \\
\text { resource extraction, } \\
\text { exploitation) }\end{array}$ & $\begin{array}{l}\text { Crop cover } \\
\text { Pasture cover } \\
\text { Urban cover } \\
\text { Forest loss } \\
\text { Livestock density }\end{array}$ & $\begin{array}{l}\text { Destructive demersal fishing } \\
\text { Low by-catch demersal fishing } \\
\text { High by-catch demersal fishing } \\
\text { Low by-catch pelagic fishing } \\
\text { High by-catch pelagic fishing }\end{array}$ \\
\hline $\begin{array}{c}\text { Human population } \\
\text { density }\end{array}$ & Population density & Coastal population density \\
\hline Pollution & $\begin{array}{l}\text { Atmospheric nitrogen deposition } \\
\text { Nitrogen fertilizer application } \\
\text { Pesticide application } \\
\text { Light pollution }\end{array}$ & $\begin{array}{c}\text { Ocean pollution } \\
\text { Fertilizer coastal pollution } \\
\text { Pesticide coastal pollution } \\
\text { Light pollution }\end{array}$ \\
\hline Alien potential & $\begin{array}{l}\text { Connectivity (transport } \\
\text { infrastructure) }\end{array}$ & Port cargo volume \\
\hline
\end{tabular}


Barlow, J., Lennox, G.D., Ferreira, J., Berenguer, E., Lees, A.C., Mac Nally, R., Thomson, J.R., Ferraz, S.F.D., Louzada, J., Oliveira, V.H.F., Parry, L., Solar, R.R.D., Vieira, I.C.G., Aragao, L., Begotti, R.A., Braga, R.F., Cardoso, T.M., de Oliveira, R.C., Souza, C.M., Moura, N.G., Nunes, S.S., Siqueira, J.V., Pardini, R., Silveira, J.M., Vaz-de-Mello, F.Z., Veiga, R.C.S., Venturieri, A. \& Gardner, T.A. (2016) Anthropogenic disturbance in tropical forests can double biodiversity loss from deforestation. Nature, 535, 144-+.

Barnosky, A.D., Matzke, N., Tomiya, S., Wogan, G.O.U., Swartz, B., Quental, T.B., Marshall, C., McGuire, J.L., Lindsey, E.L., Maguire, K.C., Mersey, B. \& Ferrer, E.A. (2011) Has the Earth's sixth mass extinction already arrived? Nature, 471, 51-57.

Blackburn, T.M., Bellard, C. \& Ricciardi, A. (2019) Alien versus native species as drivers of recent extinctions. Frontiers in Ecology and the Environment, 17, 203-207.

Bonebrake, T.C., Guo, F., Dingle, C., Baker, D.M., Kitching, R.L. \& Ashton, L.A. (2019) Integrating Proximal and Horizon Threats to Biodiversity for Conservation. Trends in Ecology \& Evolution.

Bowler, D.E., Hof, C., Haase, P., Kroncke, I., Schweiger, O., Adrian, R., Baert, L., Bauer, H.G., Blick, T., Brooker, R.W., Dekoninck, W., Domisch, S., Eckmann, R., Hendrickx, F., Hickler, T., Klotz, S., Kraberg, A., Kuhn, I., Matesanz, S., Meschede, A., Neumann, H., O'Hara, R., Russell, D.J., Sell, A.F., Sonnewald, M., Stoll, S., Sundermann, A., Tackenberg, O., Turkay, M., Valladares, F., van Herk, K., van Klink, R., Vermeulen, R., Voigtlander, K., Wagner, R., Welk, E., Wiemers, M., Wiltshire, K.H. \& Bohning-Gaese, K. (2017) Cross-realm assessment of climate change impacts on species' abundance trends. Nature Ecology \& Evolution, 1, 7.

CIESIN (2017) Gridded Population of the World, Version 4 (GPWv4): Population Density, Revision 10. Palisades, NY: NASA Socioeconomic Data and Applications Center (SEDAC). (ed. C.f.I.E.S.I.N.-C.-C. University).

Cote, I.M., Darling, E.S. \& Brown, C.J. (2016) Interactions among ecosystem stressors and their importance in conservation. Proceedings of the Royal Society B-Biological Sciences, 283.

Davidson, I.C., Scianni, C., Minton, M.S. \& Ruiz, G.M. (2018) A history of ship specialization and consequences for marine invasions, management and policy. Journal of Applied Ecology, 55, 1799-1811.

De Schrijver, A., De Frenne, P., Ampoorter, E., Van Nevel, L., Demey, A., Wuyts, K. \& Verheyen, K. (2011) Cumulative nitrogen input drives species loss in terrestrial ecosystems. Global Ecology and Biogeography, 20, 803-816.

Dentener, F.J. (2006) Global Maps of Atmospheric Nitrogen Deposition, 1860, 1993, and 2050. ORNL DAAC. Oak Ridge, Tennessee, USA.

Diaz, S., Demissew, S., Carabias, J., Joly, C., Lonsdale, M., Ash, N., Larigauderie, A., Adhikari, J.R., Arico, S., Baldi, A., Bartuska, A., Baste, I.A., Bilgin, A., Brondizio, E., Chan, K.M.A., Figueroa, V.E., Duraiappah, A., Fischer, M., Hill, R., Koetz, T., Leadley, P., Lyver, P., Mace, G.M., Martin-Lopez, B., Okumura, M., Pacheco, D., Pascual, U., Perez, E.S., Reyers, B., Roth, E., Saito, O., Scholes, R.J., Sharma, N., Tallis, H., Thaman, R., Watson, R., Yahara, T., Hamid, Z.A., Akosim, C., Al-Hafedh, Y., Allahverdiyev, R., Amankwah, E., Asah, S.T., Asfaw, Z., Bartus, G., Brooks, L.A., Caillaux, J., Dalle, G., Darnaedi, D., Driver, A., Erpul, G., Escobar-Eyzaguirre, P., Failler, P., Fouda, A.M.M., Fu, B., Gundimeda, H., Hashimoto, S., Homer, F., Lavorel, S., Lichtenstein, G., Mala, W.A., Mandivenyi, W., Matczak, P., Mbizvo, C., Mehrdadi, M., Metzger, J.P., Mikissa, J.B., Moller, H., Mooney, H.A., Mumby, P., Nagendra, H., Nesshover, C., Oteng-Yeboah, A.A., Pataki, G., Roue, M., Rubis, J., Schultz, M., Smith, P., Sumaila, R., Takeuchi, K., Thomas, S., Verma, M., Yeo-Chang, Y. \& Zlatanova, D. (2015) The IPBES Conceptual Framework - connecting nature and people. Current Opinion in Environmental Sustainability, 14, 1-16.

Dornelas, M., Gotelli, N.J., McGill, B., Shimadzu, H., Moyes, F., Sievers, C. \& Magurran, A.E. (2014) Assemblage Time Series Reveal Biodiversity Change but Not Systematic Loss. Science, 344, 296-299.

Dornelas, M., Gotelli, N.J., Shimadzu, H., Moyes, F., Magurran, A.E. \& McGill, B.J. (2019) A balance of winners and losers in the Anthropocene. Ecology Letters, 22, 847-854.

Dutilleul, P., Pelletier, B. \& Alpargu, G. (2008) Modified F tests for assessing the multiple correlation between one spatial process and several others. Journal of Statistical Planning and Inference, 138, 1402-1415.

Dyer, E.E., Cassey, P., Redding, D.W., Collen, B., Franks, V., Gaston, K.J., Jones, K.E., Kark, S., Orme, C.D.L. \& Blackburn, T.M. (2017) The Global Distribution and Drivers of Alien Bird Species Richness. Plos Biology, 15.

Ellis, E.C., Goldewijk, K.K., Siebert, S., Lightman, D. \& Ramankutty, N. (2010) Anthropogenic transformation of the biomes, 1700 to 2000. Global Ecology and Biogeography, 19, 589-606. 
Foden, W.B., Butchart, S.H.M., Stuart, S.N., Vie, J.C., Akcakaya, H.R., Angulo, A., DeVantier, L.M., Gutsche, A., Turak, E., Cao, L., Donner, S.D., Katariya, V., Bernard, R., Holland, R.A., Hughes, A.F., O'Hanlon, S.E., Garnett, S.T., Sekercioglu, C.H. \& Mace, G.M. (2013) Identifying the World's Most Climate Change Vulnerable Species: A Systematic Trait-Based Assessment of all Birds, Amphibians and Corals. Plos One, 8.

Friedl, M.A., Sulla-Menashe, D., Tan, B., Schneider, A., Ramankutty, N., Sibley, A. \& Huang, X. (2010) MODIS Collection 5 global land cover: Algorithm refinements and characterization of new datasets, 2001-2012, Collection 5.1 IGBP Land Cover. Boston University, Boston, MA, USA.

Fritz, S., See, L., McCallum, I., You, L.Z., Bun, A., Moltchanova, E., Duerauer, M., Albrecht, F., Schill, C., Perger, C., Havlik, P., Mosnier, A., Thornton, P., Wood-Sichra, U., Herrero, M., Becker-Reshef, I., Justice, C., Hansen, M., Gong, P., Aziz, S.A., Cipriani, A., Cumani, R., Cecchi, G., Conchedda, G., Ferreira, S., Gomez, A., Haffani, M., Kayitakire, F., Malanding, J., Mueller, R., Newby, T., Nonguierma, A., Olusegun, A., Ortner, S., Rajak, D.R., Rocha, J., Schepaschenko, D., Schepaschenko, M., Terekhov, A., Tiangwa, A., Vancutsem, C., Vintrou, E., Wu, W.B., van der Velde, M., Dunwoody, A., Kraxner, F. \& Obersteiner, M. (2015) Mapping global cropland and field size. Global Change Biology, 21, 1980-1992.

Geary, W.L., Nimmo, D.G., Doherty, T.S., Ritchie, E.G. \& Tulloch, A.I.T. (2019) Threat webs: reframing the cooccurrence and interactions of threats to biodiversity. Journal of Applied Ecology.

Geiger, F., Bengtsson, J., Berendse, F., Weisser, W.W., Emmerson, M., Morales, M.B., Ceryngier, P., Liira, J., Tscharntke, T., Winqvist, C., Eggers, S., Bommarco, R., Part, T., Bretagnolle, V., Plantegenest, M., Clement, L.W., Dennis, C., Palmer, C., Onate, J.J., Guerrero, I., Hawro, V., Aavik, T., Thies, C., Flohre, A., Hanke, S., Fischer, C., Goedhart, P.W. \& Inchausti, P. (2010) Persistent negative effects of pesticides on biodiversity and biological control potential on European farmland. Basic and Applied Ecology, 11, 97105 .

Halpern, B.S., Frazier, M., Potapenko, J., Casey, K.S., Koenig, K., Longo, C., Lowndes, J.S., Rockwood, R.C., Selig, E.R., Selkoe, K.A. \& Walbridge, S. (2015a) Spatial and temporal changes in cumulative human impacts on the world's ocean. Nature Communications, $\mathbf{6}$.

Halpern, B.S., Longo, C., Lowndes, J.S.S., Best, B.D., Frazier, M., Katona, S.K., Kleisner, K.M., Rosenberg, A.A., Scarborough, C. \& Selig, E.R. (2015b) Patterns and Emerging Trends in Global Ocean Health. Plos One, 10.

Halpern, B.S., Walbridge, S., Selkoe, K.A., Kappel, C.V., Micheli, F., D'Agrosa, C., Bruno, J.F., Casey, K.S., Ebert, C., Fox, H.E., Fujita, R., Heinemann, D., Lenihan, H.S., Madin, E.M.P., Perry, M.T., Selig, E.R., Spalding, M., Steneck, R. \& Watson, R. (2008) A global map of human impact on marine ecosystems. Science, 319, 948-952.

Hansen, A.J. \& DeFries, R. (2007) Ecological mechanisms linking protected areas to surrounding lands. Ecological Applications, 17, 974-988.

Harris, I., Jones, P.D., Osborn, T.J. \& Lister, D.H. (2014) Updated high-resolution grids of monthly climatic observations - the CRU TS3.10 Dataset. International Journal of Climatology, 34, 623-642.

Harrison, S. \& Cornell, H. (2008) Toward a better understanding of the regional causes of local community richness. Ecology Letters, 11, 969-979.

Hijmans, R.J. (2017) raster: Geographic Data Analysis and Modeling. R package version

2.6-7. https://CRAN.R-project.org/package=raster.

Hulme, P.E. (2009) Trade, transport and trouble: managing invasive species pathways in an era of globalization. Journal of Applied Ecology, 46, 10-18.

Hurtt, G.C., Chini, L.P., Frolking, S., Betts, R.A., Feddema, J., Fischer, G., Fisk, J.P., Hibbard, K., Houghton, R.A., Janetos, A., Jones, C.D., Kindermann, G., Kinoshita, T., Goldewijk, K.K., Riahi, K., Shevliakova, E., Smith, S., Stehfest, E., Thomson, A., Thornton, P., van Vuuren, D.P. \& Wang, Y.P. (2011) Harmonization of land-use scenarios for the period 1500-2100: 600 years of global gridded annual land-use transitions, wood harvest, and resulting secondary lands. Climatic Change, 109, 117-161.

IPBES (2019) Summary for policymakers of the global assessment report on biodiversity and ecosystem services of the Intergovernmental Science-Policy Platform on Biodiversity and Ecosystem Services. IPBES secretariat, Bonn, Germany.

IPCC (2013) Climate Change 2013: The Physical Science Basis. Contribution of Working Group I to the Fifth Assessment Report of the Intergovernmental Panel on Climate Change Cambridge University Press, Cambridge, United Kingdom and New York, NY, USA. 
Isbell, F., Gonzalez, A., Loreau, M., Cowles, J., Diaz, S., Hector, A., Mace, G.M., Wardle, D.A., O'Connor, M.I., Duffy, J.E., Turnbull, L.A., Thompson, P.L. \& Larigauderie, A. (2017) Linking the influence and dependence of people on biodiversity across scales. Nature, 546, 65-72.

Jeschke, J. \& Pyšek, P. (2018) Ten rules. CAB International, Wallingford.

Joppa, L.N., O'Connor, B., Visconti, P., Smith, C., Geldmann, J., Mann, M.H., Watson, J.E.M., Butchart, S.H.M., Virah-Sawmy, M., Halpern, B.S., Ahmed, S.E., Balmford, A., Sutherland, W.J., Harfoot, M., HiltonTaylor, C., Foden, W., Di Minin, E., Pagad, S., Genovesi, P., Hutton, J. \& Burgess, N.D. (2016) Filling in biodiversity threat gaps. Science, 352, 416-418.

Katsanevakis, S., Wallentinus, I., Zenetos, A., Leppakoski, E., Cinar, M.E., Ozturk, B., Grabowski, M., Golani, D. \& Cardoso, A.C. (2014) Impacts of invasive alien marine species on ecosystem services and biodiversity: a pan-European review. Aquatic Invasions, 9, 391-423.

Knapp, S., Schweiger, O., Kraberg, A., Asmus, H., Asmus, R., Brey, T., Frickenhaus, S., Gutt, J., Kuhn, I., Liess, M., Musche, M., Portner, H.O., Seppelt, R., Klotz, S. \& Krause, G. (2017) Do drivers of biodiversity change differ in importance across marine and terrestrial systems - Or is it just different research communities' perspectives? Science of the Total Environment, 574, 191-203.

Loarie, S.R., Duffy, P.B., Hamilton, H., Asner, G.P., Field, C.B. \& Ackerly, D.D. (2009) The velocity of climate change. Nature, 462, 1052-U1111.

Maechler, M., Rousseeuw, P., Struyf, A., Hubert, M. \& Hornik, K. (2018) cluster: Cluster Analysis Basics and Extensions. R package version 2.0.7-1.

Mazor, T., Doropoulos, C., Schwarzmueller, F., Gladish, D.W., Kumaran, N., Merkel, K., Di Marco, M. \& Gagic, V. (2018) Global mismatch of policy and research on drivers of biodiversity loss. Nature Ecology \& Evolution, 2, 1071-+.

Newbold, T., Hudson, L.N., Hill, S.L.L., Contu, S., Lysenko, I., Senior, R.A., Borger, L., Bennett, D.J., Choimes, A., Collen, B., Day, J., De Palma, A., Diaz, S., Echeverria-Londono, S., Edgar, M.J., Feldman, A., Garon, M., Harrison, M.L.K., Alhusseini, T., Ingram, D.J., Itescu, Y., Kattge, J., Kemp, V., Kirkpatrick, L., Kleyer, M., Correia, D.L.P., Martin, C.D., Meiri, S., Novosolov, M., Pan, Y., Phillips, H.R.P., Purves, D.W., Robinson, A., Simpson, J., Tuck, S.L., Weiher, E., White, H.J., Ewers, R.M., Mace, G.M., Scharlemann, J.P.W. \& Purvis, A. (2015) Global effects of land use on local terrestrial biodiversity. Nature, 520, 45-+.

Olson, D.M., Dinerstein, E., Wikramanayake, E.D., Burgess, N.D., Powell, G.V.N., Underwood, E.C., D'Amico, J.A., Itoua, I., Strand, H.E., Morrison, J.C., Loucks, C.J., Allnutt, T.F., Ricketts, T.H., Kura, Y., Lamoreux, J.F., Wettengel, W.W., Hedao, P. \& Kassem, K.R. (2001) Terrestrial ecoregions of the worlds: A new map of life on Earth. Bioscience, 51, 933-938.

Pagad, S., Genovesi, P., Carnevali, L., Schigel, D. \& McGeoch, M.A. (2018) Data Descriptor: Introducing the Global Register of Introduced and Invasive Species. Scientific Data, 5.

Parmesan, C. \& Yohe, G. (2003) A globally coherent fingerprint of climate change impacts across natural systems. Nature, 421, 37-42.

Pereira, H.M., Navarro, L.M. \& Martins, I.S. (2012) Global Biodiversity Change: The Bad, the Good, and the Unknown. Annual Review of Environment and Resources, Vol 37 (eds A. Gadgil \& D.M. Liverman), pp. 25-+.

Pithan, F. \& Mauritsen, T. (2014) Arctic amplification dominated by temperature feedbacks in contemporary climate models. Nature Geoscience, 7, 181-184.

Poloczanska, E.S., Brown, C.J., Sydeman, W.J., Kiessling, W., Schoeman, D.S., Moore, P.J., Brander, K., Bruno, J.F., Buckley, L.B., Burrows, M.T., Duarte, C.M., Halpern, B.S., Holding, J., Kappel, C.V., O'Connor, M.I., Pandolfi, J.M., Parmesan, C., Schwing, F., Thompson, S.A. \& Richardson, A.J. (2013) Global imprint of climate change on marine life. Nature Climate Change, 3, 919-925.

Potter, P., Ramankutty, N., Bennett, E.M. \& Donner, S.D. (2010) Characterizing the Spatial Patterns of Global Fertilizer Application and Manure Production. Earth Interactions, 14, 1-22.

R Core Team (2018) R: A language and environment for statistical computing. R Foundation for Statistical Computing, Vienna, Austria. URL https://www.R-project.org/.

Ramankutty, N., Evan, A.T., Monfreda, C. \& Foley, J.A. (2008) Farming the planet: 1. Geographic distribution of global agricultural lands in the year 2000. Global Biogeochemical Cycles, 22.

Ramirez, F., Afan, I., Davis, L.S. \& Chiaradia, A. (2017) Climate impacts on global hot spots of marine biodiversity. Science Advances, 3. 
Rayner, N.A., Parker, D.E., Horton, E.B., Folland, C.K., Alexander, L.V., Rowell, D.P., Kent, E.C. \& Kaplan, A. (2003) Global analyses of sea surface temperature, sea ice, and night marine air temperature since the late nineteenth century. Journal of Geophysical Research-Atmospheres, 108.

Robinson, T.P., Wint, G.R.W., Conchedda, G., Van Boeckel, T.P., Ercoli, V., Palamara, E., Cinardi, G., D'Aietti, L., Hay, S.I. \& Gilbert, M. (2014) Mapping the Global Distribution of Livestock. Plos One, 9.

Salafsky, N., Salzer, D., Stattersfield, A.J., Hilton-Taylor, C., Neugarten, R., Butchart, S.H.M., Collen, B., Cox, N., Master, L.L., O'Connor, S. \& Wilkie, D. (2008) A standard lexicon for biodiversity conservation: Unified classifications of threats and actions. Conservation Biology, 22, 897-911.

Sanderson, E.W., Jaiteh, M., Levy, M.A., Redford, K.H., Wannebo, A.V. \& Woolmer, G. (2002) The human footprint and the last of the wild. Bioscience, 52, 891-904.

Seebens, H., Essl, F., Dawson, W., Fuentes, N., Moser, D., Pergl, J., Pyšek, P., van Kleunen, M., Weber, E., Winter, M. \& Blasius, B. (2015) Global trade will accelerate plant invasions in emerging economies under climate change. Global Change Biology, 21, 4128-4140.

Sirami, C., Caplat, P., Popy, S., Clamens, A., Arlettaz, R., Jiguet, F., Brotons, L. \& Martin, J.L. (2017) Impacts of global change on species distributions: obstacles and solutions to integrate climate and land use. Global Ecology and Biogeography, 26, 385-394.

Spalding, M.D., Fox, H.E., Halpern, B.S., McManus, M.A., Molnar, J., Allen, G.R., Davidson, N., Jorge, Z.A., Lombana, A.L., Lourie, S.A., Martin, K.D., McManus, E., Molnar, J., Recchia, C.A. \& Robertson, J. (2007) Marine ecoregions of the world: A bioregionalization of coastal and shelf areas. Bioscience, 57, 573-583.

Sunday, J.M., Pecl, G.T., Frusher, S., Hobday, A.J., Hill, N., Holbrook, N.J., Edgar, G.J., Stuart-Smith, R., Barrett, N., Wernberg, T., Watson, R.A., Smale, D.A., Fulton, E.A., Slawinski, D., Feng, M., Radford, B.T., Thompson, P.A. \& Bates, A.E. (2015) Species traits and climate velocity explain geographic range shifts in an ocean-warming hotspot. Ecology Letters, 18, 944-953.

Tittensor, D.P., Walpole, M., Hill, S.L.L., Boyce, D.G., Britten, G.L., Burgess, N.D., Butchart, S.H.M., Leadley, P.W., Regan, E.C., Alkemade, R., Baumung, R., Bellard, C., Bouwman, L., Bowles-Newark, N.J., Chenery, A.M., Cheung, W.W.L., Christensen, V., Cooper, H.D., Crowther, A.R., Dixon, M.J.R., Galli, A., Gaveau, V., Gregory, R.D., Gutierrez, N.L., Hirsch, T.L., Hoft, R., Januchowski-Hartley, S.R., Karmann, M., Krug, C.B., Leverington, F.J., Loh, J., Lojenga, R.K., Malsch, K., Marques, A., Morgan, D.H.W., Mumby, P.J., Newbold, T., Noonan-Mooney, K., Pagad, S.N., Parks, B.C., Pereira, H.M., Robertson, T., Rondinini, C., Santini, L., Scharlemann, J.P.W., Schindler, S., Sumaila, U.R., Teh, L.S.L., van Kolck, J., Visconti, P. \& Ye, Y.M. (2014) A mid-term analysis of progress toward international biodiversity targets. Science, 346, 241-244.

Tucker, M.A., Bohning-Gaese, K., Fagan, W.F., Fryxell, J.M., Van Moorter, B., Alberts, S.C., Ali, A.H., Allen, A.M., Attias, N., Avgar, T., Bartlam-Brooks, H., Bayarbaatar, B., Belant, J.L., Bertassoni, A., Beyer, D., Bidner, L., van Beest, F.M., Blake, S., Blaum, N., Bracis, C., Brown, D., de Bruyn, P.J.N., Cagnacci, F., Calabrese, J.M., Camilo-Alves, C., Chamaille-Jammes, S., Chiaradia, A., Davidson, S.C., Dennis, T., DeStefano, S., Diefenbach, D., Douglas-Hamilton, I., Fennessy, J., Fichtel, C., Fiedler, W., Fischer, C., Fischhoff, I., Fleming, C.H., Ford, A.T., Fritz, S.A., Gehr, B., Goheen, J.R., Gurarie, E., Hebblewhite, M., Heurich, M., Hewison, A.J.M., Hof, C., Hurme, E., Isbell, L.A., Janssen, R., Jeltsch, F., Kaczensky, P., Kane, A., Kappeler, P.M., Kauffman, M., Kays, R., Kimuyu, D., Koch, F., Kranstauber, B., LaPoint, S., Leimgruber, P., Linnell, J.D.C., Lopez-Lopez, P., Markham, A.C., Mattisson, J., Medici, E.P., Mellone, U., Merrill, E., Mourao, G.D., Morato, R.G., Morellet, N., Morrison, T.A., Diaz-Munoz, S.L., Mysterud, A., Nandintsetseg, D., Nathan, R., Niamir, A., Odden, J., O'Hara, R.B., Oliveira-Santos, L.G.R., Olson, K.A., Patterson, B.D., de Paula, R.C., Pedrotti, L., Reineking, B., Rimmler, M., Rogers, T.L., Rolandsen, C.M., Rosenberry, C.S., Rubenstein, D.I., Safi, K., Said, S., Sapir, N., Sawyer, H., Schmidt, N.M., Selva, N., Sergiel, A., Shiilegdamba, E., Silva, J.P., Singh, N., Solberg, E.J., Spiegel, O., Strand, O., Sundaresan, S., Ullmann, W., Voigt, U., Wall, J., Wattles, D., Wikelski, M., Wilmers, C.C., Wilson, J.W., Wittemyer, G., Zieba, F., Zwijacz-Kozica, T. \& Mueller, T. (2018) Moving in the Anthropocene: Global reductions in terrestrial mammalian movements. Science, 359, 466-469.

Vallejos, R., Osorio, F. \& Bevilacqua, M. (2018) Spatial Relationships Between Two Georeferenced Variables: with Applications in R. Springer, New York.

van Kleunen, M., Pyšek, P., Dawson, W., Essl, F., Kreft, H., Pergl, J., Weigelt, P., Stein, A., Dullinger, S., Konig, C., Lenzner, B., Maurel, N., Moser, D., Seebens, H., Kartesz, J., Nishino, M., Aleksanyan, A., Ansong, M., Antonova, L.A., Barcelona, J.F., Breckle, S.W., Brundu, G., Cabezas, F.J., Cardenas, D., Cardenas-Toro, J., Castano, N., Chacon, E., Chatelain, C., Conn, B., de Sa Dechoum, M., Dufour-Dror, J.M., Ebel, A.L., 
Figueiredo, E., Fragman-Sapir, O., Fuentes, N., Groom, Q.J., Henderson, L., Inderjit, Jogan, N., Krestov, P., Kupriyanov, A., Masciadri, S., Meerman, J., Morozova, O., Nickrent, D., Nowak, A., Patzelt, A., Pelser, P.B., Shu, W.S., Thomas, J., Uludag, A., Velayos, M., Verkhosina, A., Villasenor, J.L., Weber, E., Wieringa, J.J., Yazlik, A., Zeddam, A., Zykova, E. \& Winter, M. (2019) The Global Naturalized Alien Flora (GloNAF) database. Ecology, 100.

Venter, O., Sanderson, E.W., Magrach, A., Allan, J.R., Beher, J., Jones, K.R., Possingham, H.P., Laurance, W.F., Wood, P., Fekete, B.M., Levy, M.A. \& Watson, J.E.M. (2016) Sixteen years of change in the global terrestrial human footprint and implications for biodiversity conservation. Nature Communications, 7.

Vorosmarty, C.J., McIntyre, P.B., Gessner, M.O., Dudgeon, D., Prusevich, A., Green, P., Glidden, S., Bunn, S.E., Sullivan, C.A., Liermann, C.R. \& Davies, P.M. (2010) Global threats to human water security and river biodiversity. Nature, 467, 555-561.

Waters, C.N., Zalasiewicz, J., Summerhayes, C., Barnosky, A.D., Poirier, C., Galuszka, A., Cearreta, A., Edgeworth, M., Ellis, E.C., Ellis, M., Jeandel, C., Leinfelder, R., McNeill, J.R., Richter, D.D., Steffen, W., Syvitski, J., Vidas, D., Wagreich, M., Williams, M., An, Z.S., Grinevald, J., Odada, E., Oreskes, N. \& Wolfe, A.P. (2016) The Anthropocene is functionally and stratigraphically distinct from the Holocene. Science, 351, 137-+.

Zorner, R.J., Trabucco, A., Bossio, D.A. \& Verchot, L.V. (2008) Climate change mitigation: A spatial analysis of global land suitability for clean development mechanism afforestation and reforestation. Agriculture Ecosystems \& Environment, 126, 67-80. 